\title{
Increase of Tangible and Intangible Fixed Assets in the Manufacturing Industry in Romania under the Impact of Foreign Direct Investment
}

\author{
Corneliu Russu \\ Centre for Industry and Services’ Economy, Romanian Academy, 125 Calea Victoriei, Sector 1, 010071, \\ Bucharest, Romania \\ e-mail: corneliu_russu2007@yahoo.com
}

DOI: 10.51865/EITC.2021.02.01

\begin{abstract}
The article deals with the main aspects of the materialization of foreign direct investment (FDI) made in the component activities of the manufacturing industry in tangible and intangible fixed assets (TIFA), that serve the development of productive processes in those activities. Starting from the idea that for manufacturing activities the importance of each of the two categories of fixed assets varies depending on the specifics of each activity, the analysis reveals the existence of significant differences between the materialization of FDI in TIFA in these activities and the gross value added generated by them, as well as between the stock of tangible assets realized by FDI and the total value of TIFA registered in the manufacturing activities. The conclusion of the analysis is that the TIFA made by FDI substantially improved the quality of the productive apparatus of the manufacturing activities and, implicitly, their productivity and competitiveness; the activities with the greatest benefits in this regard were Machinery and equipment, Means of transport, Computers, electronic, optical and electrical products, and Crude oil processing, chemical products, rubber and plastics.
\end{abstract}

Key words: tangible fixed assetts; intangible fixed assetts; gross value added; the stock of tangible and intangible fixed assets.

JEL Classification: D24; L6; O16.

\section{Introduction}

The materialization of FDI in TIFA is of particular importance for efforts to refurbish and modernize the economy and manufacturing industry, whereas, by their nature, they ensure longterm stability for those investments. The analysis of the changes produced in the volume and structure of these fixed assets allows the identification of the orientation of foreign investment, and provides relevant information regarding the future stability of the investment made.

Tangible fixed assets are non-financial produced assets that consist of: dwellings, other buildings (industrial buildings, commercial buildings, hotels and restaurants, educational buildings, hospitals a.s.o.); structures (highways, streets, railways, airfields a.s.o.); machinery and equipment (transport equipment, radio, television and communication equipment, medical instruments, furniture, musical instruments a.s.o.); plantations and livestock (according to the 
definition of the National Institute of Statistics. Statistical Yearbook of Romania 2019, Chapter 12, p. 432).

The intangible fixed assets are non-monetary assets, identifiable, without material support, used in the processes of production or supply of goods and / or services, intended for rent to third parties or for administrative purposes. These fixed assets include: the expenses for setting up and developing companies; patents, licenses, trademarks, concessions, rights and similar assets, except those created internally; goodwill; advances granted to suppliers of intangible fixed assets; intangible fixed assets under construction.

The nature of a fixed asset comprising tangible and intangible items shall be determined whether it is tangible or intangible according to the most significant item; for example, software for a computerized machine is included in the amount of this tangible fixed asset; on the other hand, the software distinct from that hardware constitutes an intangible fixed asset. Intangible assets arising from research are not recognized.

\section{TIFA in the Component Activities of the Manufacturing Industry}

The two definitions give a clear picture of the major importance that both categories of fixed assets have for the development of the economy and society. For manufacturing activities, the importance of one or the other of the two categories of fixed assets varies within wide limits, depending on the specifics of each activity; in the Metallurgy or in the Machinery and equipment industry, tangible fixed assets have the majority share; in the activity Computers, electronic, optical and electrical products, intangible fixed assets are predominant, etc.

In the manufacturing industry, the weight of component activities in the TIFA stock at the end of the reference years evolved according to the figures in the following table.

Table 1. The weight of processing activities in the TIFA stock achieved by FDI at the end of the year, 2007 .... $2019(\%)$

\begin{tabular}{|l|c|c|c|c|c|c|}
\hline & $\mathbf{2 0 0 7}$ & $\mathbf{2 0 1 0}$ & $\mathbf{2 0 1 2}$ & $\mathbf{2 0 1 5}$ & $\mathbf{2 0 1 7}$ & $\mathbf{2 0 1 9}$ \\
\hline Manufacturing industry & 100.0 & 100.0 & 100.0 & 100.0 & 100.0 & 100.0 \\
\hline $\begin{array}{l}\text { Food products, beverages, tobacco } \\
\text { products }\end{array}$ & 15.5 & 15.3 & 13.3 & 11.7 & 12.4 & 13.4 \\
\hline Cement, glass, ceramics & 9.2 & 10.0 & 10.6 & 8.0 & 7.7 & 6.7 \\
\hline $\begin{array}{l}\text { Woodworking, products of wood, } \\
\text { including furniture }\end{array}$ & 8.4 & 7.1 & 7.4 & 8.7 & 5.4 & 3.2 \\
\hline $\begin{array}{l}\text { Computers, electronic, optical and } \\
\text { electrical products }\end{array}$ & 5.5 & 4.3 & 4.5 & 5.6 & 7.4 & 8.6 \\
\hline $\begin{array}{l}\text { Machinery and equipment } \\
\text { Metallurgy }\end{array}$ & 2.3 & 5.1 & 5.5 & 6.1 & 5.8 & 8.1 \\
\hline Means of transport & 13.5 & 17.8 & 17.5 & 18.5 & 25.4 & 25.2 \\
\hline $\begin{array}{l}\text { Crude oil processing, chemical } \\
\text { products, plastics and rubber }\end{array}$ & 12.5 & 15.9 & 17.2 & 20.0 & 17.3 & 18.4 \\
\hline $\begin{array}{c}\text { Textiles, wearing apparel, leather and } \\
\text { leather goods }\end{array}$ & 5.4 & 4.8 & 4.2 & 4.2 & 4.4 & 3.4 \\
\hline Other manufacturing activities n.e.c. & 4.7 & 2.6 & 3.0 & 3.0 & 3.3 & 3.0 \\
\hline
\end{tabular}

Source: Own calculations based on data from the National Bank of Romania. Foreign investment in Romania in the year 2007, Bucharest, 2007, and subsequent editions corresponding to the years in the table.

The picture of the evolution in the analyzed period of the weight of manufacturing activities depending on the level of this indicator differs significantly from the structural changes produced depending on the value of the realized production or that of the gross added value. 
Manufacturing activities in which the upward dynamics of the stock of fixed assets was much higher than that recorded in the manufacturing industry as a whole (155.7\%) were, in descending order, Machinery and equipment (381.7\%), Means of transport (290, 5\%), Computers, other electronic, optical and electrical products (243.0\%), Crude oil processing, chemical products, rubber and plastics (229.7\%); most of them are activities with high technological intensity, with appreciable potential to increase the added value produced and of major importance in the modernization of the economy and society. Investments in the modernization of the productive apparatus of these activities and in their intangible fixed assets have substantially contributed to improving their economic and financial performance and competitiveness.

The activities in which the value of TIFA performed by FDI in 2019 was lower than in 2007 were Woodworking, products of wood, including furniture (58.1\%), Metallurgy (70.8\%) and Textiles, wearing apparel, leather goods $(99.6 \%)$.

Finally, the Food products, beverages, tobacco products, and Cement, glass, ceramics activities benefited from significant increases in the TIFA stock, which improved the quality of their productive apparatus and increased the possibilities of superior capitalizing on the comparative and competitive advantages they present.

The comparison between the weights of the component activities according to the gross value added achieved on the manufacturing industry as a whole (see the following table) and the weights of the same activities in the TIFA volume realized by FDI within them reveals interesting aspects.

Table 2. Weights of component activities in gross value added produced by the manufacturing industry, 2007-2017 (\%)

\begin{tabular}{|c|c|c|c|c|c|}
\hline & 2007 & 2010 & 2012 & 2015 & 2017 \\
\hline Manufacturing industry & 100.0 & 100.0 & 100.0 & 100.0 & 100.0 \\
\hline $\begin{array}{l}\text { Food products, beverages, tobacco } \\
\text { products }\end{array}$ & 27.0 & 25.4 & 27.0 & 23.2 & 23.7 \\
\hline Cement, glass, ceramics & 5.4 & 2.3 & 4.0 & 3.8 & 3.6 \\
\hline $\begin{array}{l}\text { Woodworking, products of wood, } \\
\text { including furniture }\end{array}$ & 10.8 & 9.9 & 8.3 & 8.1 & 7.9 \\
\hline $\begin{array}{l}\text { Computers, electronic, optical and } \\
\text { electrical products }\end{array}$ & 9.1 & 12.4 & 8.2 & 9.2 & 8.0 \\
\hline Machinery and equipment & 3.3 & 4.0 & 4.3 & 4.0 & 4.2 \\
\hline Metallurgy & 10.4 & 10.5 & 13.0 & 8.7 & 8.8 \\
\hline Means of transport & 11.1 & 14.8 & 9.5 & 11.3 & 15.7 \\
\hline $\begin{array}{l}\text { Crude oil processing, chemical } \\
\text { products, plastics and rubber }\end{array}$ & 10.9 & 5.4 & 9.0 & 17.1 & 14.5 \\
\hline $\begin{array}{l}\text { Textiles, wearing apparel, leather and } \\
\text { leather goods }\end{array}$ & 9.5 & 9.8 & 10.8 & 9.6 & 8.5 \\
\hline Other manufacturing activities n.e.c. & 2.5 & 5.6 & 5.9 & 5.0 & 5.2 \\
\hline
\end{tabular}

Source: Own calculations based on data: for the years 2007, 2010, 2012 - National Institute of Statistics. Romanian Statistical Yearbook 2014, Table 11.12.; for the years 2015 and 2017; National Institute of Statistics. Statistical Yearbook of Romania 2019, Table 11.12.

The activities that registered, in the period 2007-2017, increases of their share in the gross value added realized on the whole manufacturing industry were, in descending order, Other manufacturing activities n.e.c. (2.08 times), Means of transport (1.41 times), Crude oil processing, chemical products, rubber and plastics (1.33 times), and Machinery and equipment (1.27 times). The increases were made on the basis of TIFA increase, materialized in improving the technical condition of their productive apparatus, assimilating better technologies, improving the quality structure of manufactured products, increasing the competitiveness of 
these products, progressive and increasingly efficient integration of Romanian producers in international value chains.

The other activities, mostly traditional, have reduced their share whereas they have characteristics - obsolete and slow-improving technologies, low-skilled workforce, lower TIFA volume - which explains the reduction in their share in the manufacturing industry as a whole.

Returning to the above mentioned comparison, the changes in the weight of some manufacturing activities expressed in $+/$ - percentage points differ greatly between their contribution to the production of gross value added and the volume of TIFA made by FDI within them, as shown by the figures in the following figure.

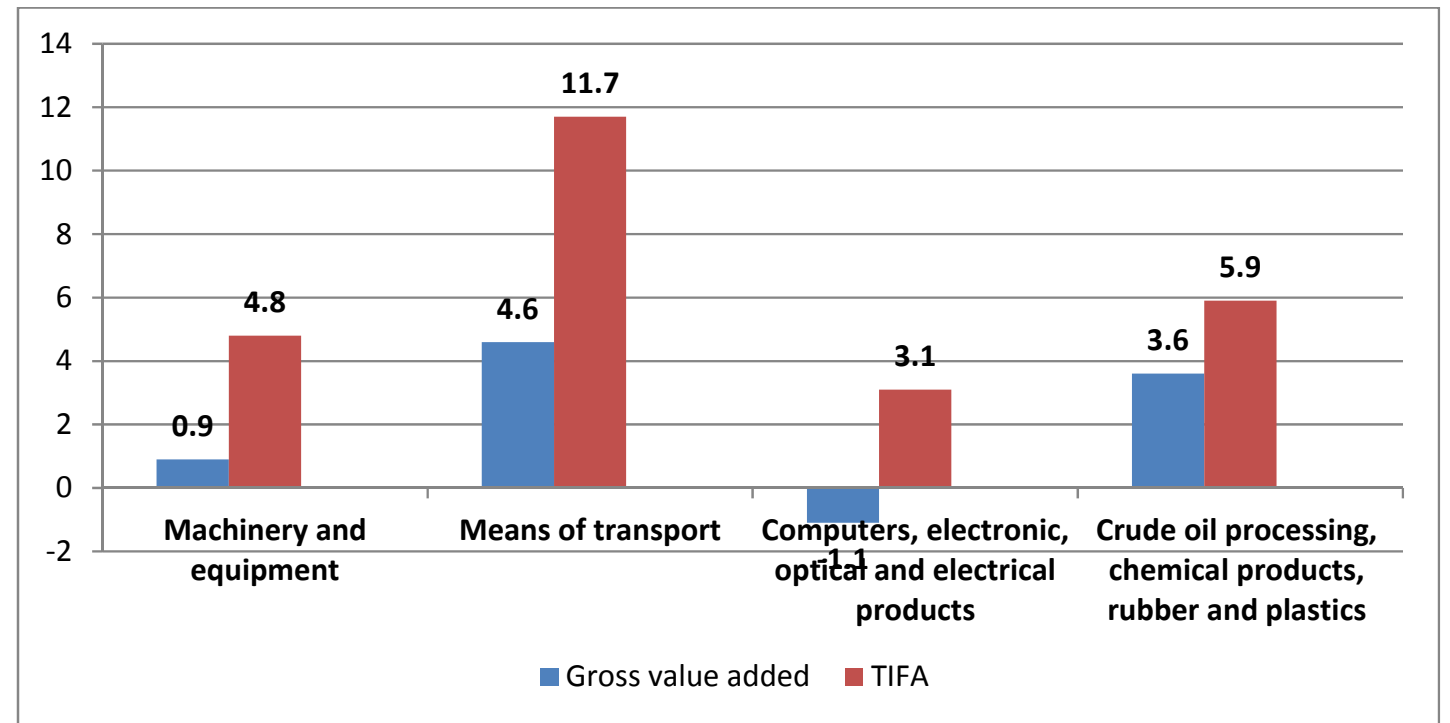

Fig. 1. Changes in the weight of some manufacturing activities depending on the gross value added produced and the volume of TIFA achieved by FDI within them, 2017/2007 (percentage points)

Source: Own calculations based on data from the National Bank of Romania. Foreign investment in Romania in the year 2007, Bucharest, 2007, and subsequent editions corresponding to the years in the table.

The differences show that the increases recorded by the weight of these activities in the period 2007-2017 (2017 is the last year in which the Romanian Statistical Yearbook presents data on gross value added produced by manufacturing activities) by TIFA balance are higher than those recorded depending on their contribution to gross value added on manufacturing industry; in other words, FDI in fixed assets did not lead to a significant improvement in the share of activities present in the figure depending on their potential to generate gross value added.

\section{Ratio TIFA Stock/FDI Stock in Manufacturing Industry and its Component Activities}

The comparison of the TIFA stock achieved by FDI in the manufacturing activities, on the basis of which the shares in Table 1 were determined, with the FDI stock accumulated in these activities, leads to interesting conclusions, resulting from the figures presented in the following table.

In the manufacturing industry as a whole and in eight of its component activities, the ratio decreased, due to the fact that in the first years of the analyzed period it invested predominantly in TIFA for the refurbishment and modernization of the productive apparatus, after which these actions largely attained their the purpose and, as a result, those investments have diminished. 
The sharpest decrease was recorded in the activity of Woodworking, products of wood, including furniture, by 42.7 points, but also other activities showed significant reductions: Cement, glass, ceramics - by 23.8 points, Other manufacturing activities - by 21.7 points, Textiles, wearing apparel, leather and leather goods - by 17.6 points, Metallurgy - by 16.7 points, Means of transport - by 16.6 points, Crude oil processing, chemical products, rubber and plastics - with 10.4 points, Computers, electronic, optical and electrical products - with 1.1 points.

Table 3. Ratio TIFA stock achieved by FDI / FDI stock by manufacturing industry and its activities, 2007 .... 2019

\begin{tabular}{|l|c|c|c|c|c|c|}
\hline & $\mathbf{2 0 0 7}$ & $\mathbf{2 0 1 0}$ & $\mathbf{2 0 1 2}$ & $\mathbf{2 0 1 5}$ & $\mathbf{2 0 1 7}$ & $\mathbf{2 0 1 9}$ \\
\hline Manufacturing industry & 62.1 & 56.9 & 57.5 & 60.2 & 51.3 & 53.2 \\
\hline $\begin{array}{l}\text { Food products, beverages, tobacco } \\
\text { products }\end{array}$ & 61.5 & 70.3 & - & 65.0 & 62.0 & 69.1 \\
\hline Cement, glass, ceramics & 83.8 & 57.8 & - & 65.9 & 68.5 & 60.0 \\
\hline $\begin{array}{l}\text { Woodworking, products of wood, } \\
\text { including furniture }\end{array}$ & 72.2 & 67.0 & - & 61.2 & 51.0 & 29.5 \\
\hline $\begin{array}{l}\text { Computers, electronic, optical and } \\
\text { electrical products }\end{array}$ & 58.6 & 49.2 & - & 45.0 & 50.4 & 57.5 \\
\hline Machinery and equipment & 53.8 & 51.9 & - & 42.5 & 43.0 & 57.3 \\
\hline Metallurgy & 59.7 & 58.9 & - & 64.0 & 43.5 & 43.0 \\
\hline Means of transport & 76.5 & 65.7 & - & 67.4 & 57.1 & 59.9 \\
\hline $\begin{array}{c}\text { Crude oil processing, chemical } \\
\text { products, rubber and plastics }\end{array}$ & 58.4 & 42.2 & - & 62.1 & 44.6 & 48.0 \\
\hline $\begin{array}{c}\text { Textiles, wearing apparel, leather and } \\
\text { leather goods }\end{array}$ & 63.5 & 54.9 & - & 50.4 & 52.3 & 45.9 \\
\hline \begin{tabular}{l} 
Other manufacturing activities n.e.c. \\
\hline
\end{tabular} & 67.7 & 52.2 & - & 63.1 & 62.7 & 46.0 \\
\hline
\end{tabular}

Source: Own calculations based on data from the National Bank of Romania. Foreign investment in Romania in the year 2007, Bucharest, 2007, and subsequent editions corresponding to the years in the table.

The only activity in which the decrease of the ratio occurred in the conditions of the reduction of both the FDI stock and the TIFA stock was Metallurgy; among the other manufacturing activities mentioned as decreasing the ratio, Woodworking, products of wood, including furniture, and Textiles, wearing apparel, leather and leather goods presented, during the analyzed period, divergences in the evolution of the two terms of the report (increasing the FDI stock, reducing the TIFA stock), and in the other activities the two terms evolved in the same direction, that of growth. Such different developments in some activities of the two indicators and their ratio are the result of the various needs for refurbishment and modernization of their productive apparatus, as well as the also varied growth rates of activities (when the growth rate of an activity decreases continuously on long term or becomes negative, the interest of foreign investors for that activity decreases accordingly).

The only activities in which the value of the ratio increased were Food products, beverages, tobacco products - by 7.6 points, and Machinery and equipment - by 3.5 points. The first activity reduced its share in the manufacturing industry according to both the value of production and the gross value added achieved, but the increasing value of the ratio shows that there is still a need to improve its productive apparatus; foreign investors have understood that they must meet this need in order to capitalize on the comparative and competitive advantages that the respective activities present and, thus, to increase their profit. The second activity is expanding, it has increased its share in the manufacturing industry, it has registered, in the analyzed period, the biggest increases of the FDI stock and of the TIFA stock; the increase in the value of the ratio shows the same growing interest of foreign investors in revitalizing this industry, which experienced a sharp decline after 1990 despite its positive characteristics - long tradition in Romania's economy, skilled labor, technical expertise. 
The further increase in the inflow of FDI and TIFA achieved by FDI in these two activities would be a welcome prospect of a significant increase in their productive and commercial potential, with the most substantial effects on ensuring food security of the population and, respectively, increasing appreciable contribution of the second activity to GDP growth.

The comparison of the evolution in the analyzed period of the share of manufacturing activities in the TIFA stock made by FDI in the manufacturing industry with that of the share of the same activities in the value of tangible assets in the same industry highlights, in most cases, convergent trends (see table below).

Table 4. Weight of manufacturing activities in the TIFA stock achieved by FDI and in the value of tangible fixed assets on the manufacturing industry, 2007 .... 2019 (\%)

\begin{tabular}{|c|c|c|c|c|c|c|c|c|c|c|c|c|}
\hline & \multicolumn{2}{|c|}{2007} & \multicolumn{2}{|c|}{2010} & \multicolumn{2}{|c|}{2012} & \multicolumn{2}{|c|}{2015} & \multicolumn{2}{|c|}{2017} & \multicolumn{2}{|c|}{2019} \\
\hline & $\begin{array}{l}\text { TIFA } \\
\text { stock }\end{array}$ & $\begin{array}{l}\text { Tan- } \\
\text { gible } \\
\text { fixed } \\
\text { assets } \\
\end{array}$ & $\begin{array}{l}\text { TIFA } \\
\text { stock }\end{array}$ & $\begin{array}{l}\text { Tan- } \\
\text { gible } \\
\text { fixed } \\
\text { assets } \\
\end{array}$ & $\begin{array}{l}\text { TIFA } \\
\text { stock }\end{array}$ & $\begin{array}{l}\text { Tan- } \\
\text { gible } \\
\text { fixed } \\
\text { assets } \\
\end{array}$ & $\begin{array}{l}\text { TIFA } \\
\text { stock }\end{array}$ & $\begin{array}{l}\text { Tan- } \\
\text { gible } \\
\text { fixed } \\
\text { assets } \\
\end{array}$ & $\begin{array}{l}\text { TIFA } \\
\text { stock }\end{array}$ & $\begin{array}{l}\text { Tan- } \\
\text { gible } \\
\text { fixed } \\
\text { assets } \\
\end{array}$ & $\begin{array}{l}\text { TIFA } \\
\text { stock }\end{array}$ & $\begin{array}{c}\text { Tan- } \\
\text { gible } \\
\text { fixed } \\
\text { assets * } \\
\end{array}$ \\
\hline $\begin{array}{l}\text { Food products, } \\
\text { beverages, } \\
\text { tobacco products }\end{array}$ & 15.5 & 18.2 & 15.3 & 19.1 & 13.3 & 18.2 & 11.7 & 16.7 & 12.4 & 16.3 & 13.4 & 16.7 \\
\hline $\begin{array}{l}\text { Cement, glass, } \\
\text { ceramics }\end{array}$ & 9.2 & 8.3 & 10.0 & 9.3 & 10.6 & 8.1 & 8.0 & 7.7 & 7.7 & 6.5 & 6.7 & 6.5 \\
\hline $\begin{array}{l}\text { Wood-working, } \\
\text { products of } \\
\text { wood, including } \\
\text { furniture }\end{array}$ & 8.4 & 10.5 & 7.1 & 9.8 & 7.4 & 9.4 & 8.7 & 10.1 & 5.4 & 10.3 & 3.2 & 9.3 \\
\hline $\begin{array}{l}\text { Computers, } \\
\text { electronic, optical } \\
\text { and electrical } \\
\text { products }\end{array}$ & 5.5 & 8.2 & 4.3 & 6.0 & 4.5 & 7.1 & 5.6 & 6.6 & 7.4 & 6.7 & 8.6 & 7.2 \\
\hline $\begin{array}{l}\text { Machinery and } \\
\text { equipment }\end{array}$ & 3.3 & 6.1 & 5.1 & 5.5 & 5.5 & 6.1 & 6.1 & 6.8 & 5.8 & 6.1 & 8.1 & 6.1 \\
\hline Metallurgy & 22.0 & 14.0 & 17.1 & 14.3 & 16.8 & 14.7 & 14.2 & 14.4 & 10.9 & 13.4 & 10.0 & 13.4 \\
\hline $\begin{array}{l}\text { Means of } \\
\text { transport }\end{array}$ & 13.5 & 10.9 & 17.8 & 12.1 & 17.5 & 14.0 & 18.5 & 15.4 & 25.4 & 18.9 & 25.2 & 18.8 \\
\hline $\begin{array}{l}\text { Crude oil } \\
\text { processing, } \\
\text { chemical } \\
\text { products, rubber } \\
\text { and plastics } \\
\end{array}$ & 12.5 & 15.0 & 15.9 & 16.9 & 17.2 & 16.2 & 20.0 & 16.1 & 17.3 & 16.1 & 18.4 & 16.2 \\
\hline $\begin{array}{l}\text { Textiles, wearing } \\
\text { apparel, leather } \\
\text { and leather goods }\end{array}$ & 5.4 & 7.9 & 4.8 & 5.8 & 4.2 & 5.0 & 4.2 & 4.7 & 4.4 & 4.4 & 3.4 & 4.4 \\
\hline $\begin{array}{l}\text { Other } \\
\text { manufactu-ring } \\
\text { activities n.e.c. }\end{array}$ & 4.7 & 0.9 & 2.6 & 1.2 & 3.0 & 1.2 & 3.0 & 1.5 & 3.3 & 1.3 & 3.0 & 1.4 \\
\hline
\end{tabular}

Note: * - Year 2018.

Source: Own calculations based on data from: for the weight by the TIFA stock made by FDI - National Bank of Romania. Foreign direct investments in Romania in the year 2007, Bucharest, 2007, and subsequent editions corresponding to the years in the table; for the shares based on tangible fixed assets Romanian Statistical Yearbook 2007, 2008 edition, Table 12.12.; for the year 2010 - 2011 edition, Table 12.7.; for the year 2012, 2013 edition, Table 12.10.; for the years 2015, 2017, and 2018 - 2019 edition, Table 12.7.

Such a comparison makes it possible to highlight the convergence or divergence of developments in the reference period of the weights of the processing activities established according to the two indicators.

In this sense, in the variations of the respective weights some dominant aspects and tendencies can be identified:

o the similar senses of the evolution in the period 2017-2018 of the weights established according to both indicators in most manufacturing activities (seven out of ten);

o the different shock felt by the activities under the impact of the global crisis of 2008-2010 and which was also reflected in very different variations in the evolution of the share of activities in the period 2007-2010 (only the activities Means of transport, Crude oil processing, chemical products, rubber and plastics, Textiles, wearing apparel, leather and 
leather goods, and Other manufacturing activities n.e.c. have evolved in the same direction of their share according to both indicators);

o divergent developments of the weights determined according to the two indicators of activities Computers, electronic, optical and electrical products (increase based on TIFA stock, decrease based on tangible fixed assets), Machinery and equipment (increase based on TIFA stock, level with fluctuations but at the same value in 2018 compared to 2007 based on the tangible fixed assets, and Other manufacturing activities n.e.c.(decrease based on TIFA stock, increase based on tangible fixed assets);

o the largest increases in the share determined based on the two indicators of activities that recorded the most substantial increases in the FDI stock - Means of transport, Crude oil processing, chemical products, rubber and plastics;

o the still modest level of activity Machinery and equipment established on the basis of both indicators, despite the fact that this activity was, in the period 2007-2019, second after Means of transport to increase the FDI stock (which indicates that foreign investment has been materialized in a lower share in fixed assets).

\section{Conclusions}

The effects of FDI on the value of TIFA were materialized, mainly, in the qualitative improvement of the productive apparatus of the manufacturing activities through restructuring of production capacities, their refurbishment and modernization.

The largest increases in the TIFA stock made by FDI were, in descending order of manufacturing activities, Machinery and equipment (but modest in value compared to the following activity), Means of transport, Computers, electronic, optical and electrical products (also modest in value compared to the previous activity), and Crude oil processing, chemical products, rubber and plastics. In these activities and groups of activities, Means of transport and Rubber and plastic products experienced the largest increases in the value of production and competitiveness, determined, predominantly, by the large volume of TIFA they recorded.

Among the traditional activities - characterized by a low level of technological intensity and modest added value -, in Food products, beverages, tobacco products, and Cement, glass, ceramics the FDI stock increased in 2019 compared to 2007, also contributing to the improvement of their performances. In the other activities in this category - Woodworking, products of wood, including furniture, Metallurgy, Textiles, wearing apparel, leather and leather goods - the TIFA stock decreased in various proportions, but those activities continued to record high export performance, which indicates that they capitalized on other resources besides TIFA to improve their production and trade potential.

\section{References}

1. Alwafi, Y.M. (2017). Trade Openness, Foreign Direct Investment and Infrastructure Spending: A Comparative Analysis of their Common Role in the Economic Development Between Selected Developed and Developing Economies. Master Thesis. 3300, Eastern Illinois University, The Keep.

2. Amighiani, A., McMillan, M. and Sanfilippo, M. (2017). Foreign Direct Investment and Capital Formation in Developing Economies: New Evidence from Industry-level Data, Working Paper 23049, National Bureau of Economic Research, Cambridge, MA, January.

3. Bevan, A.A. and Estrin, S. (2004). The Determinants of Foreign Direct Investment into European Transition Economies, Journal of Comparative Economics, vol. 32 no. 4, pp.775-87.

4. Biswas, R. (2002). Determinants of foreign direct investment, Review of Development Economics, 6 (3), pp. 492-504.

5. Bonciu, F. (2011). Investitiile străine directe înainte şi după criza economică mondială, Universitary Publishing House, Bucharest. 
6. Botric,V. and Skulic. L. (2005). Main Determinants of Foreign Direct Investment in the South East European Countries. Trade, FDI and Relocation: Challenge for Employment and Growth in the European Union, 2nd Euroframe Conference on Economic Policy Issues in the European Union, Vienna.

7. Corrado, C. and Jona-Lasinio, C. (2020). Intangible capital, innovation, and productivity à la Jorgenson evidence for Europe and the United States, in: Measuring Economic Growth and Productivity: Foundations, KLEMS Production Models, and Extensions, 1st Edition, Academic Press, 2020.

8. Daianu, D. (2001). Winners and losers in the process of European integration. A look at Romania, Romanian Center for Economic Policies, Bucharest.

9. Falk, M. (2013).New empirical findings for international investment in intangible assets, WWWforEurope Working Paper, No. 30, WWWforEurope, Vienna.

10. Gorg, H. and Greenaway D. (2002). Much Ado About Nothing? Do Domestic Firms Really Benefit from Foreign Direct Investment?, Research Paper 2001/37.

11. Hansen, H. and Rand, J. (2006). On the Causal Links Between FDI and Growth in Developing Countries, The World Economy, 29 (1), pp. 21-41.

12. Hanson, G. (2001). Should Countries Promote Foreign Direct Investment?, G-24 Discussion Papers 9 , United Nations Conference on Trade and Development.

13. Johnson, A. (2006). The Effects of FDI Inflows on Host Country Economic Growth, CESIS Working Paper Series, Royal Institute of Technology, Sweden.

14. Kalotay K. (2008). FDI in Romania and Bulgaria in the Wake of the EU Accession, Journal of East West Business, 14.

15. Krkoska, L. (2001). Foreign direct investment financing of capital formation in Central and Eastern Europe. Working paper No. 67, European Bankof Reconstruction and Development, UK, 2001.

16. Lipsey, R. E. (2001). Foreign Direct Investment and the operations of multinational firms: concepts, history, and data, Working paper 8665, National Bureau of Economic Research, Cambridge (USA).

17. Lipsey, R. E. Home and Host Country Effects of FDI, Lidingö, Sweden, 2002.

18. National Institute of Statistics. Statistical Yearbook of Romania, different annual editions, Bucharest.

19. Roth, F. and Thum, A.-E. (2010). Does intangible capital affect economic growth?. Centre for European Policy Studies, CEPS Working Document No. 335 / September.

20. Sachwald, F. (2005). The Impact of EU Enlargement on the Location of Production in Europe, Les Etudes de l'IFRI 4 (IFRI), Paris, p.56.

21. Organisation for Economic Cooperation and Development (1996). Benchmark Definition of Foreign Direct Investment, 3rd Edition, Paris.

22. UNCTAD (2017). World Investment Report, 2017, New York and Geneva.

23. UNCTAD (2018). World Investment Report, 2018, New York and Geneva.

24. UNCTAD (2019). World Investment Report, 2019, New York and Geneva.

25. World Economic Forum (2019). The Global Competitiveness Report 2019, Geneva.

26. World Economic Forum (2020). The Global Competitiveness Report Special Edition 2020: How

Countries Are Performing on the Road to Recovery, Geneva.

27. Wright, J. and Zhu, B. (2018). Monopoly Rents and Foreign Direct Investment in Fixed Assets, International Studies Quarterly, Volume 62, Issue 2, June, pp. 341-356. 